\title{
Progesterone induced blocking factor in health and disease
}

\author{
Julia Szekeres-Bartho $0^{1,2,3,4^{*}}$ \\ ${ }^{1}$ Department of Medical Biology and Central Electron Microscope Laboratory, Medical School, Pecs University, 7624 \\ Pecs, Hungary \\ ${ }_{2}^{2}$ János Szentágothai Research Centre, Pecs University, 7624 Pecs, Hungary \\ ${ }^{3}$ MTA-PTE Human Reproduction Research Group, 7624 Pecs, Hungary \\ ${ }^{4}$ National Laboratory for Human Reproduction, 7624 Pecs, Hungary
}

*Correspondence: Julia Szekeres-Bartho, Department of Medical Biology and Central Electron Microscope Laboratory, Medical School, Pecs University, 12 Szigeti Street, 7624 Pecs, Hungary. Szekeres.julia@pte.hu

Academic Editor: Satish Kumar Gupta, Indian Council of Medical Research, India

Received: September 14, 2021 Accepted: November 15, 2021 Published: December 31, 2021

Cite this article: Szekeres-Bartho J. Progesterone induced blocking factor in health and disease. Explor Immunol. 2021;1:406-17. https://doi.org/10.37349/ei.2021.00027

\begin{abstract}
The foetus expressing paternal antigens ought to be "rejected" by the maternal immune system. However, the immunological relationship of the mother and the foetus does not follow the rules of transplantation immunology. Maternal immune functions are re-adjusted during pregnancy, to create a tolerant environment for the developing foetus. Progesterone and its downstream mediator; the progesterone induced blocking factor (PIBF) are important in this process. The mRNA transcribed from the PIBF1 gene contains 18 exons, and codes for a $90 \mathrm{kDa}$ protein. The $90 \mathrm{kDa}$ form is associated with the centrosome and plays a role in cell cycle regulation, while smaller isoforms produced by alternative spicing are secreted, and bind to the glycosylphosphatidylinositol (GPI) anchored PIBF receptor. Upon ligation, the former forms a heterodimer with the alpha chain of the interleukin-4 (IL-4) receptor and activates the Janus kinase/signal transducers and activators of transcription (Jak/STAT) pathway, via which, PIBF induces increased production of $\mathrm{T}$ helper2 (Th2) cytokines. PIBF regulates natural killer (NK) cytotoxicity, by inhibiting perforin release from the cytoplasmic granules of NK cells. During normal human pregnancy, the serum concentrations of PIBF increase with gestational age, and lower than normal serum levels predict spontaneous pregnancy termination. Depletion of PIBF during the peri-implantation period in mice, results in lower implantation and increased resorption rates, together with increased decidual and peripheral NK activity, downregulation of the genes implicated in $\mathrm{T}$ cell activation in $\mathrm{CD}^{+}$cells, and Th1 differentiation of the T cells. PIBF is expressed in rapidly proliferating immature cells as well as several tumours, and regulates invasion. The PIBF gene has been identified in the chromosomal region 13q21-q22-which is a common site for somatic deletions in a variety of malignant tumours. These data suggest that PIBF might be involved in tumorigenesis.
\end{abstract}

\section{Keywords}

Progesterone, progesterone induced blocking factor, pregnancy, tumour, cytokines, invasion 


\section{Introduction}

Progesterone is critical for pregnancy in most mammalian species. In humans, progesterone production gradually rises during gestation to reach a level of $100-500 \mathrm{~nm}$ in the sera of pregnant women and 1-10 $\mu \mathrm{m}$ in placental tissue. Decades ago, it became evident, that in addition to its endocrine effects, progesterone mediates interactions between the endocrine and immune systems. It has been shown that high concentrations of progesterone inhibit the activation and killing of T cells [1-3], and extend the survival of allogeneic grafts implanted in hamster uteri [4, 5]. In 1997, Siiteri et al. [6] reported that progesterone was able to influence the function of peripheral lymphocytes. The lowest effective concentration was $10 \mu \mathrm{g} / \mathrm{mL}$, which is approximately 100 -fold higher than the concentrations found in maternal blood in the 3rd trimester of pregnancy, but relevant to those, found at the foeto-maternal interface [7]. They assumed that the immune-modulating effects of progesterone might account for the acceptance of the semi-allogeneic foetus by the maternal immune system, and they called progesterone "nature's immunosuppressant".

By comparing the effect of progesterone on pregnancy- and non-pregnancy lymphocytes, it became obvious that the former responded to 100 -fold lower concentrations than non-pregnancy lymphocytes [8]. The remarkable difference in progesterone sensitivity suggested the presence of specific binding sites in lymphocytes of pregnant, but not in those of non-pregnant women.

\section{Lymphocyte progesterone receptors}

The existence of progesterone receptors (PRs) in pregnancy lymphocytes was only confirmed later, when progesterone receptor-specific antibodies became available. In 1989, together with Gerard Chaouat we demonstrated PRs in peripheral pregnancy-, but not, in non-pregnancy lymphocytes, and showed that the percentage of $\mathrm{PR}^{+}$peripheral lymphocytes increase throughout normal gestation $[9,10]$. The percentage of PR-expressing lymphocytes from women with recurrent miscarriages, pre-term delivery was significantly lower than in those from healthy pregnant women of corresponding gestational ages [9], suggesting a relationship between lymphocyte PR expression and pregnancy outcome.

PR induction in the lymphocytes is an activation-related phenomenon. Exposure of non-pregnancy lymphocytes to mitogenic or alloantigenic stimuli increases PR expression [11]. In circulating lymphocytes of liver transplanted patients of both sexes, the expression of PRs is comparable to that of pregnant women [12], suggesting that allogeneic stimulation by itself is sufficient for inducing PRs. Lymphocyte PR expression is thus, not a consequence of the altered hormonal environment during pregnancy, rather that of the alloantigenic stimulation by the fetal antigens. This concept gained further support from the finding, that paternal leukocyte immunization of women with recurrent miscarriages increased PR expression in lymphocytes [13]. Taken together, these data indicate that lymphocyte activation is responsible for the induction of PRs in immune cells.

The effect of progesterone on the immune system of pregnant women is at least in part receptor-mediated $[9,10,13-16]$, however not all immune cells have been confirmed to express PRs. Purified decidual NK cells do not express PRs [17], while both classical PR-A and B have been demonstrated in killer cell immunoglobulin-like receptors $\left(\mathrm{KIR}^{+}\right)$, but not in KIR- peripheral blood NK cells [18]. Almost $70 \%$ of decidual $\mathrm{T}$ cells express the $\gamma / \delta \mathrm{T}$ cell receptor $[19,20], \gamma / \delta \mathrm{T}$ cells are able to recognize unprocessed foreign antigens in a major histocompatibility complex (MHC) non-restricted manner, and most decidual $\gamma / \delta \mathrm{T}$ cell are activated [19-22], therefore, they are likely candidates for recognizing trophoblast presented fetal antigens. The majority of $\mathrm{PR}^{+}$circulating pregnancy lymphocytes express the $\gamma / \delta$ T cell receptor [23,24]. These cells might be of decidual origin, where they became activated by trophoblast-presented foetal antigens.

\section{Progesterone-induced blocking factor}

Hormone binding induces structural alterations in the steroid receptor, which enables DNA binding [25] and the induction of genes, resulting in protein synthesis. The progesterone-induced blocking 
factor $(P I B F)$ is one of the progesterone-regulated genes and the resulting protein is responsible for the immunomodulatory effects of progesterone [26, 27].

The mRNA transcribed from the PIBF1 gene contains 18 exons, and codes for a $90 \mathrm{kDa}$ protein [28] which is a source of several smaller isoforms. The full length PIBF and the small isoforms exert different functions. The $90 \mathrm{kDa}$ form is associated with the nucleus and has been identified as a component of the peri-centriolar satellite [29,30]. The smaller forms are localized in the cytoplasm [29]. The former has a role in cell cycle regulation, while the small isoforms are secreted and bind to the glycosylphosphatidylinositol (GPI) anchored PIBF receptor [31]. Digesting the anchoring region of the receptor results in a loss of the immunological effects of PIBF [31], furthermore, GPI deficiency is associated with infertility in female mice [32]. The receptor does not have a trans-membrane domain, therefore, following ligand binding forms a temporary association with the alpha chain of the interleukin-4 (IL-4) receptor and signals via the Janus kinase/signal transducers and activators of transcription (JAK/STAT) pathway [31].

\section{The immunological effects of PIBF}

The two major subsets of $\mathrm{T}$ helper (Th) cells include Th1 and Th2 cells with different cytokine production profiles. The Th1 subset secretes the Th1 cytokines, e.g., interferon- $\gamma$ (IFN- $\gamma$ ), tumor necrosis factor- $\beta$ (TNF- $\beta$ ), TNF- $\alpha$, IL-2, which induce strong cell-mediated and inflammatory reactions. Th 2 cells, on the other hand, secrete the Th2 cytokines IL-4, IL-5, IL-6, IL-10, and IL-13, which stimulate antibody production. During the major part of normal human pregnancy, the balance of Th1 and Th2 cytokines is shifted towards Th2. The absence of the Th2 dominant cytokine pattern might result in reproductive failure [33, 34], as shown by the fact, that peripheral blood mononuclear cells from women with recurrent spontaneous pregnancy loss secrete Th1 type cytokines upon activation [35, 36].

Upon engagement the PIBF receptor forms a heterocomplex with the alpha chain of the IL-4 receptor, and this explains the effect of PIBF on cytokine synthesis. Signalling via the IL-4 receptor results in increased production of Th2 type cytokines, by which PIBF contributes to the Th2 dominant cytokine pattern during normal pregnancy (Figure 1).

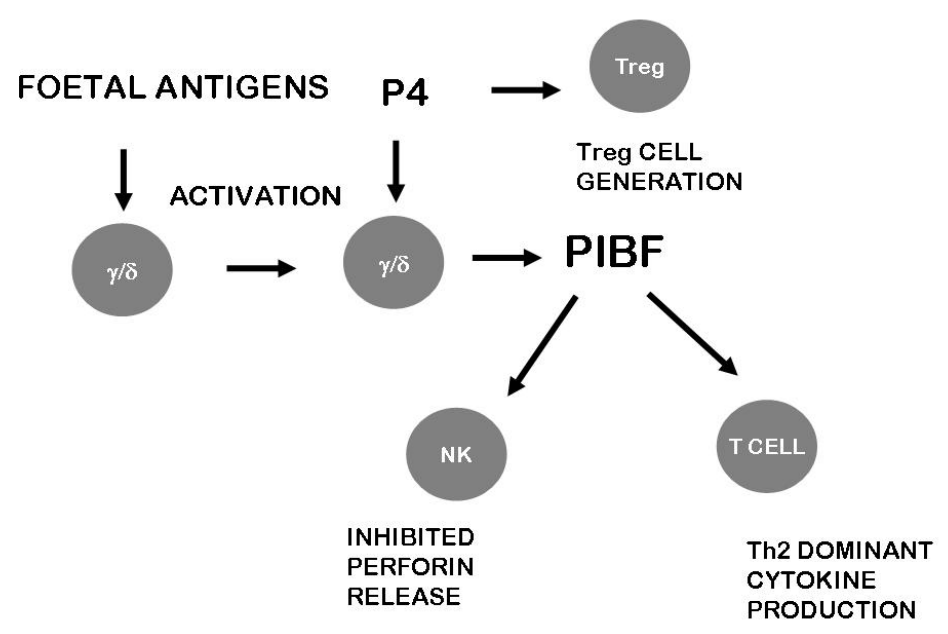

Figure 1. The effects of PIBF on the immune system. Following activation by foetal antigens, maternal lymphocytes express PRs, and in the presence of progesterone, produce PIBF. The small PIBF isoforms bind to the PIBF receptor and activate signaling pathways that lead to increased production of Th2 cytokines. By inhibiting degranulation of NK cells, PIBF contributes to the low NK activity. These together with the positive effect of progesterone on regular T (Treg) cell generation are crucial for moderating anti foetal immune reaction

PIBF treatment results in elevated IL-4 and IL-10 production by peripheral lymphocytes of non-pregnant mice [37]. A prospective clinical trial [38] on women with recurrent miscarriage showed that dydrogesterone treatment induced PIBF production, which down-regulated peripheral Th1 and stimulated Th2 type cytokine production. 
PIBF treatment of lymphocytes from women with pre-term delivery inhibited the originally high production of Th1 type cytokines and stimulated the production of Th2 type cytokines [38, 39]. A recent study revealed that the T cells of PIBF-deficient pregnant mice differentiate towards Th1 [40].

Th1/Th2/Th17 immunity [41-43] and Treg cell generation [44] are also affected by progesterone. Tregs isolated from pregnancy blood express membrane PRs. Furthermore, the number of membrane progesterone receptor positive Tregs increases throughout gestation and drops before delivery, suggesting that the pregnancy protective effect of progesterone is partly mediated via Treg cell action [45].

PIBF also affects NK activity in several ways. Several studies reported increased peripheral NK activity in women suffering from miscarriages of unknown aetiology [46-50].

In mice high peripheral NK activity results in fetal loss [51]. Adoptive transfer of high NK activity spleen cells induces resorptions in pregnant Balb/c mice [52], and the high resorption rates can be corrected by PIBF supplementation [53]. Conversely, the development of high resorption rates is counteracted by anti-NK antibody treatment [54], suggesting that PIBF protects pregnancy by keeping NK activity under control.

Granulated decidual NK cells, constitute a dominant lymphocyte population in the early decidua both in human and mice. Though these cells are fully equipped with the cytotoxic enzymes, their killing activity is low [55-57], but secrete angiogenic factors and cytokines instead [58]. PIBF is present in the cytoplasmic granules of mouse decidual NK cells [59] and by inhibiting perforin release $[60,61]$ contributes to the low cytotoxic activity of these lymphocytes (Figure 1).

\section{The effect of PIBF on arachidonic acid metabolism}

Progesterone maintains uterine quiescence until term, when the loss of progesterone results in increased prostaglandin production and the latter initiates parturition by stimulating myometrial contractility [62]. PIBF inhibits phosholipase A2, the enzyme required for the liberation of arachidonic acid [63], thus reduces the availability of the precursor for prostaglandin synthesis.

Insufficient PIBF production increases the risk of preterm labour [64], however, intervening at a different point of the mechanism might allow pregnancy to go to term.

Treatment of women at risk for preterm delivery with low dose aspirin, inhibiting the cyclooxygenase enzyme, resulted in a significantly lower rate of preterm delivery [65]. In line with this, a recent randomized controlled trial showed that low dose aspirin treatment of almost 600 patients significantly prevented preterm birth, and improved perinatal mortality rates [66].

\section{PIBF in pregnancy}

PIBF is present in the urine and the sera of pregnant women. In serum samples of in vitro fertilization (IVF) patients PIBF was detected 14 days after embryo transfer [67], and later the serum concentrations increased by gestational age in uneventful pregnancies [68]. Lower than normal concentrations predict spontaneous pregnancy termination $[69,70]$ as shown by the finding that not only decidual PR and PIBF expression, but also the serum concentrations of PIBF are characteristically low in women with unexplained miscarriages in [71]. The predictive value of low PIBF levels was suggested in an earlier study showing that in the absence of detectable PIBF at three to five weeks, even seemingly normal pregnancies are at risk of miscarriage [72]. The same group demonstrated a higher percentage of $\mathrm{PIBF}^{+}$lymphocytes in pregnant than in non-pregnant women [73], as well as a positive effect of lymphocyte immunotherapy on the percentage of $\mathrm{PIBF}^{+}$cells [74]. Elective pregnancy termination with progesterone receptor antagonists resulted in a decreased percentage of PIBF positive peripheral lymphocytes [75], suggesting a relationship between the availability of progesterone-induced PIBF and the outcome of pregnancy.

In early pregnancy, PIBF induces decidual transformation of mouse endometrial stromal cells, and the endometrial expression of this protein is markedly increased during the implantation window [76], suggesting that PIBF might play a role in implantation. 
Depletion of PIBF during the peri-implantation period results in impaired implantation and increased resorption rates in mice, together with high decidual and peripheral NK activity. PIBF deficiency also causes a significant downregulation of the genes implicated in T cell activation and a Th1 type differentiation of the T cells [40].

PIBF treatment normalized the Th1/Th2 ratio, reduced the inflammation, corrected the blood pressure and prevented foetal growth restriction in a rat preeclampsia model [77].

Taken together, these data show that the immunomodulatory effects of progesterone play a role in the maintenance of normal gestation.

\section{PIBF controls trophoblast and tumour cells invasion}

RNA expression analyses of several human cell lines revealed an overexpression of PIBF mRNA in highly proliferating, immature cells. Check et al. [78] and Srivastava et al. [79], reported that several human leukemia cell lines expressed PIBF mRNA and some of them the PIBF protein. The addition of progesterone to the media increased the expression of PIBF while blocking the progesterone receptor downregulated its expression.

In tumour cells, the full-length PIBF shows a co-localization with the centrosome [29], and has been identified as a component of the pericentriolar satellite [30]. These data, together with the identification of the PIBF gene on chromosome 13, close to the site for somatic deletions in several malignant tumours [80]—suggest that PIBF might be involved in tumour development (Figure 2).

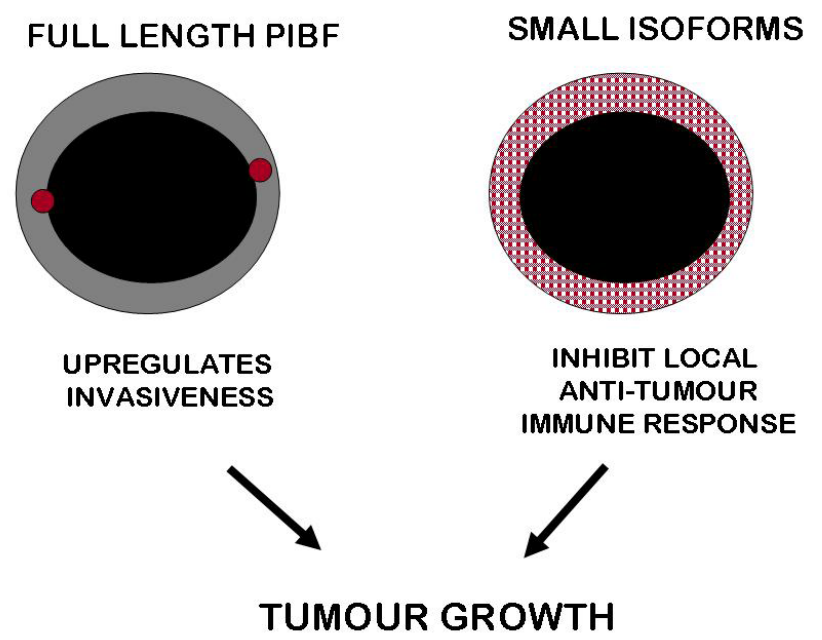

Figure 2. PIBF acts in favor of tumour progression. The full length PIBF is associated with the pericentriolar satellite and upregulates the invasiveness of tumour cells. The smaller isoforms present in the cytoplasm are secreted, and by inducing a Th2 dominant cytokine production as well as reduced NK activity, inhibit local anti-tumour immunity. These together, result in enhanced tumour growth

Controlled trophoblast invasion is a key process during human placentation and a prerequisite of successful pregnancy [81]. PIBF is expressed by the trophoblast, and also by tumours and regulates invasiveness of both tissues. The distribution of PIBF within the first trimester decidua coincides with trophoblast invasion [82]. PIBF is expressed in both normal 1st trimester villous trophoblast and in partial mole, but PIBF expression markedly decreased in complete mole and absent in choriocarcinoma [83]. These data suggest that PIBF expression is inversely related to trophoblast invasiveness.

Invasiveness is a common feature of trophoblast and malignant tumours; however, while tumour invasion is unlimited, trophoblast invasion is strictly controlled. Silencing of PIBF increased invasiveness as well as matrix metalloproteinase-2 (MMP-2) and MMP-9 secretion of trophoblast, and decreased those of tumour cells. Invasion-related signaling by PIBF was in both cell types initiated through the IL-4R $\alpha / P I B F$ receptor complex [84]. 
In vivo experiments suggest that PIBF might indeed contribute to tumour development [85]. Treatment with progesterone receptor blockers increased the length and quality of life of mice with spontaneous leukemia. Within 2 weeks of therapy only $11.4 \%$ of the mifepristone treated mice died $v s$. $50 \%$ of controls [86].

Taken together, these data show that PIBF promotes tumour growth.

\section{Conclusion}

Starting from the peri-implantation period, PIBF plays a key role during pregnancy.

PIBF induces decidual transformation of endometrial stromal cells, and its expression in the mouse endometrium peaks during the implantation window, suggesting that this molecule is required for successful implantation. PIBF deficient mice are characterized by low implantation, and later on, by high resorption rates. The latter is due to the loss of PIBF-associated immunological effects, e.g., the Th2 dominant cytokine balance and down-regulated NK activity, both of them crucial for creating a friendly immunological environment for the developing foetus. Furthermore, the lack of PIBF results in dysregulated trophoblast invasion, which might result in trophoblastic diseases or preeclampsia.

PIBF is highly expressed by malignant tumours and tumour cell lines, suggesting its role in tumour development. This molecule might promote tumour growth via different pathways. The immunological effects of the short isoforms could dampen local anti-tumour responses; the full-length molecule associated with the centrosome might interfere with the normal cell cycle, and upregulate the invasiveness of tumour cells.

Taken together, by using the same mechanisms, PIBF which promotes normal gestation, acts as a foe in malignant tumours.

\section{Abbreviations}

GPI: glycosylphosphatidylinositol

IL-4: interleukin-4

NK: natural killer

PIBF: progesterone induced blocking factor

PRs: progesterone receptors

Th2: T helper2

Treg: regular $\mathrm{T}$

\section{Declarations}

\section{Author contributions}

The author contributed solely to the work.

\section{Conflicts of interest}

The author declare that she has no conflicts of interest.

\section{Ethical approval}

Not applicable.

\section{Consent to participate}

Not applicable.

\section{Consent to publication}

Not applicable. 


\section{Availability of data and materials}

Not applicable.

\section{Funding}

This work was supported by European Social Fund (EFOP-3.6.3.-VEKOP-16-2017-00009) and the Research Grant of the University of Pecs (PTE ÁOK-KA 2017-22 EFOP-3.6.1.-16-2016-00004). The funders had no role in study design, data collection and analysis, decision to publish, or preparation of the manuscript.

\section{Copyright}

(C) The Author(s) 2021.

\section{References}

1. Mori T, Kobayashi H, Nishimoto H, Suzuki A, Nishimura T, Mori T. Inhibitory effect of progesterone and 20 alpha-hydroxypregn-4-en-3-one on the phytohemagglutinin-induced transformation of human lymphocytes. Am J Obstet Gynecol. 1977;127:151-7.

2. Pavia CS, Stites DP. Humoral and cellular regulation of alloimmunity in pregnancy. J Immunol. 1979;123:2194-200.

3. Wyle FA, Kent JR. Immunosuppression by sex steroid hormones. The effect upon PHA- and PPD-stimulated lymphocytes. Clin Exp Immunol. 1977;27:407-15.

4. Moriyama I, Sugawa T. Progesterone facilitates implantation of xenogenic cultured cells in hamster uterus. Nature New Biol. 1972;236:150-2.

5. Hansen PJ, Bazer FW, Segerson EC Jr. Skin graft survival in the uterine lumen of ewes treated with progesterone. Am J Reprod Immunol Microbiol. 1986;12:48-54.

6. Siiteri PK, Febres F, Clemens LE, Chang RJ, Gondos B, Stites D. Progesterone and maintenance of pregnancy: is progesterone nature's immunosuppressant? Ann N Y Acad Sci. 1977;286:384-97.

7. Runnebaum B, Stöber I, Zander J. Progesterone, 20 alpha-dihydroprogesterone and 20 beta-dihydroprogesterone in mother and child at birth. Acta Endocrinol (Copenh). 1975;80:569-76.

8. Szekeres-Bartho J, Hadnagy J, Pacsa AS. The suppressive effect of progesterone on lymphocyte cytotoxicity: unique progesterone sensitivity of pregnancy lymphocytes. J Reprod Immunol. 1985;7:121-8.

9. Szekeres-Bartho J, Reznikoff-Etievant MF, Varga P, Pichon MF, Varga Z, Chaouat G. Lymphocytic progesterone receptors in normal and pathological human pregnancy. J Reprod Immunol. 1989;16:239-47.

10. Szekeres-Bartho J, Szekeres G, Debre P, Autran B, Chaouat G. Reactivity of lymphocytes to a progesterone receptor-specific monoclonal antibody. Cell Immunol. 1990;125:273-83.

11. Paldi A, d'Auriol L, Misrahi M, Autran B, Chaouat G, Szekeres-Bartho J. Expression of the gene coding for the progesterone receptor in activated human lymphocytes. Endocrine Journal. 1994;2:317-21.

12. Szekeres-Bartho J, Weill BJ, Mike G, Houssin D, Chaouat G. Progesterone receptors in lymphocytes of liver-transplanted and transfused patients Immunol. Letters. 1989;22:259-61.

13. Chiu L, Nishimura M, Ishii Y, Nieda M, Maeshima M, Takedani $Y$, et al. Enhancement of the expression of progesterone receptor on progesterone-treated lymphocytes after immunotherapy in unexplained recurrent spontaneous abortion. Am J Reprod Immunol. 1996;35:552-7.

14. Piccinni MP, Giudizi MG, Biagiotti R, Beloni L, Giannarini L, Sampognaro S, et al. Progesterone favors the development of human $\mathrm{T}$ helper cells producing $\mathrm{Th2}$-type cytokines and promotes both IL-4 production and membrane CD30 expression in established Th1 cells clones. J Immunol. 1995;155:128-33. 
15. van den Heuvel M, McBey BA, Hahnel AC, Croy BA. An analysis of the uterine lymphocyte-derived hybridoma cell line GWM 1-2 for expression of receptors for estrogen, progesterone and interleukin 2. J Reprod Immunol. 1996;31:37-50.

16. Hansen KA, Opsahl MS, Nieman LK, Baker JR Jr, Klein TA. Natural killer cell activity from pregnant subjects is modulated by RU 486. Am J Obstet Gynecol. 1992;166:87-90.

17. Henderson TA, Saunders PT, Moffet-King A, Grrome NO, Critchley HO. Steroid receptor expression in uterine natural killer cells. J Clin Endocrinol Metab. 2003;88:440-9.

18. Arruvito L, Giulianelli S, Flores AC, Paladino N, Barboza M, Lanari C, et al. NK cells expressing a progesterone receptor are susceptible to progesterone-induced apoptosis. J Immunol. 2008;180:5746-53.

19. Mincheva-Nilsson L, Baranov V, Yeung MM, Hammarström S, Hammarstrom ML. Immunomorphologic studies of human decidua-associated lymphoid cells in normal early pregnancy. J Immunol. 1994;152:2020-32.

20. Liu WJ, Gottshall SL, Hansen PJ. Increased expression of cell surface markers on endometrial T cell receptor intraepithelial lymphocytes induced by the local presence of the sheep conceptus. Amer J Reprod Immunol. 1997;37:199-205.

21. Meeusen E, Fox A, Brandon M, Lee CS. Activation of uterine intraepithelial gamma delta $\mathrm{T}$ cell receptor positive lymphocytes during pregnancy. Eur J Immunol. 1993;23:1112-7.

22. Kimura M, Hanawa H, Watanabe H, Ogawa M, Abo T. Synchronous expansion of intermediate TCR cells in the liver and uterus during pregnancy. Cell Immunol. 1995;162:15-25.

23. Szekeres-Bartho J, Barakonyi A, Polgar B, Par G, Faust Z, Palkovics T, et al. The role of $\gamma / \delta$ T cells in progesterone-mediated immunomodulation during pregnancy: a review. Am J Reprod. Immunol. 1999;42:44-8.

24. Barakonyi A, Kovacs KT, Miko E, Szereday L, Varga P, Szekeres-Bartho J. Recognition of nonclassical HLA class I antigens by gamma delta T cells during pregnancy. J Immunol. 2002;168:2683-8.

25. Yamamoto K. Steroid receptor regulated transcription of specific genes and gene networks. Annu Rev Genet. 1985;19:209-52.

26. Szekeres-Bartho J, Kilar F, Falkay G, Csernus V, Torok A, Pacsa AS. The mechanism of the inhibitory effect of progesterone on lymphocyte cytotoxicity: I. Progesterone-treated lymphocytes release a substance inhibiting cytotoxicity and prostaglandin synthesis. Am Reprod Immunol Microbiol. 1985;9:15-8.

27. Szekeres-Bartho J, Autran B, Debre P, Andreu G, Denver L, Chaouat G. Immunoregulatory effects of a suppressor factor from healthy pregnant women's lymphocytes after progesterone induction. Cell Immunol. 1989;122:281-94.

28. Polgar B, Kispal G, Lachmann M, Paar C, Nagy E, Csere P, et al. Molecular cloning and immunologic characterization of a novel cDNA coding for progesterone-induced blocking factor. J Immunol. 2003;171:5956-63.

29. Lachmann M, Gelbmann D, Kálmán E, Polgár B, Buschle M, Von Gabain A, et al. PIBF (progesterone induced blocking factor) is overexpressed in highly proliferating cells and associated with the centrosome. Int J Cancer. 2004;112:51-60.

30. Kim K, Rhee K. The pericentriolar satellite protein CEP90 is crucial for integrity of the mitotic spindle pole. J Cell Sci. 2011;124:338-47.

31. Kozma N, Halasz M, Polgar B, Poehlmann TG, Markert UR, Palkovics T, et al. Progesterone-induced blocking factor activates STAT6 via binding to a novel IL-4 receptor. J Immunol. 2006;176:819-26.

32. Alfieri JA, Martin AD, Takeda J, Kondoh G, Myles DG, Primakoff P. Infertility in female mice with an oocyte-specific knockout of GPI-anchored proteins. J Cell Sci. 2003;116:2149-55. 
33. Raghupathy R. Th-1 type immunity is incompatible with successful pregnancy. Immunol Today. 1997;18:478-82.

34. Ng SC, Gilman-Sachs A, Thaker P, Beaman KD, Beer AE, Kwak-Kim J. Expression of intracellular Th1 and Th2 cytokines in women with recurrent spontaneous abortion, implantation failures after IVF/ET or normal pregnancy. Am J Reprod Immunol. 2002;48:77-86.

35. Raghupathy R, Makhseed M, Azizieh F, Omu A, Gupta M, Farhat R. Cytokine production by maternal lymphocytes during normal human pregnancy and in unexplained recurrent spontaneous abortion. Hum Reprod. 2000;15:713-8.

36. Raghupathy R, Makhseed M, Azizieh F, Hassan N, Al-Azemi M, Al-Shamali E. Maternal Th1- and Th2-type reactivity to placental antigens in normal human pregnancy and unexplained recurrent spontaneous abortions. Cell Immunol. 1999;196:122-30

37. Szekeres-Bartho J, Wegmann TG. A progesterone-dependent immuno-modulatory protein alters the Th1/Th2 balance. J Reprod Immunol. 1996;31:81-95.

38. Raghupathy R, Al Mutawa E, Makhseed M, Azizieh F, Szekeres-Bartho J. Modulation of cytokine production by dydrogesterone in lymphocytes from women with recurrent abortion. BJOG. 2005;112:1096-101.

39. Raghupathy R, Al-Mutawa E, Al-Azemi M, Makhseed M, Azizieh F, Szekeres-Bartho J. Progesterone-induced blocking factor (PIBF) modulates cytokine production by lymphocytes from women with recurrent miscarriage and with preterm delivery. J Reprod Immunol. 2009;80:91-9.

40. Csabai T, Pallinger E, Kovacs AF, Miko E, Bognar Z, Szekeres-Bartho J. Altered immune response and implantation failure in progesterone-induced blocking factor-deficient mice. Front Immunol. 2020;11:349.

41. Maeda Y, Ohtsuka H, Tomioka M, Oikawa M. Effect of progesterone on Th1/Th2/Th17 and regulatory T cell-related genes in peripheral blood mononuclear cells during pregnancy in cows. Vet Res Commun. 2013;37:43-9.

42. Lee JH, Ulrich B, Cho J, Park J, Kim CH. Progesterone promotes differentiation of human cord blood fetal $\mathrm{T}$ cells into $\mathrm{T}$ regulatory cells but suppresses their differentiation into Th17 cells. J Immunol. 2011;187:1778-87.

43. Mao G, Wang J, Kang Y, Tai P, Wen J, Zou Q et al. Progesterone increases systemic and local uterine proportions of $\mathrm{CD} 4{ }^{+} \mathrm{CD} 25^{+}$Treg cells during midterm pregnancy in mice. Endocrinology. 2010;151:5477-88.

44. Thiele K, Hierweger AM, Riquelme JIA, Solano ME, Lydon JP, Arck PC. Impaired progesterone-responsiveness of $\mathrm{CD}_{11 \mathrm{c}^{+}}$dendritic cells affects the generation of $\mathrm{CD}^{+}$regulatory $\mathrm{T}$ cells and is associated with intrauterine growth restriction in mice. Front Endocrinol (Lausanne). 2019;25:10:96.

45. Areia A, Vale-Pereira S, Alves V, Rodrigues-Santos P, Santos-Rosa M, Moura P, et al. Can membrane progesterone receptor alpha on T regulatory cells explain the ensuing human labour? J Reprod Immunol. 2016;113:22-6.

46. Ntrivalas EI, Kwak-Kim JYH, Gilman-Sachs A, Chung-Bang H, Ng SC, Beaman KD, et al. Status of peripheral blood natural killer cells in women with recurrent spontaneous abortions and infertility of unknown aetiology. Human Reprod. 2001;16:855-61.

47. Ntrivalas EI, Bowser CR, Kwak-Kim J, Beaman KD, Gilman-Sachs A. Expression of killer immunoglobulin-like receptors on peripheral blood NK cell subsets of women with recurrent spontaneous abortions or implantation failures. Am J Reprod Immunol. 2005;53:215-21.

48. Putowski L, Darmochwal-Kolarz D, Rolinski J, Oleszczuk J, Jakowicki J. The immunological profile of infertile women after repeated IVF failure (preliminary study). Eur J Obstet Gynecol Reprod Biol. 2004;112:192-6. 
49. Shakhar K, Ben-Eliyahu S, Loewenthal R, Rosenne E, Carp H. Differences in number and activity of peripheral natural killer cells in primary versus secondary recurrent miscarriage. Fertil Steril. 2003;80:368-75.

50. Yamada H, Kato EH, Kobashi G, Ebina Y, Shimada S, Morikawa M, et al. High NK cell activity in early pregnancy correlates with subsequent abortion with normal chromosomes in women with recurrent abortion. Am J Reprod Immunol. 2001;46:132-6.

51. De Fougerolles R, Baines M. Modulation of natural killer activity influences resorption rates in CBAxDBA/2 matings. J Reprod Immunol. 1987;11:147-53.

52. Kinsky R, Delage G, Rosin N, Thang MN, Hoffmann M, Chaouat G. A murine model of NK cell mediated resorption. Am J Reprod Immunol. 1990;23:73-7.

53. Szekeres-Bartho J, Kinsky R, Chaouat G. The effect of a progesterone induced immunologic blocking factor on NK-mediated resorption. Amer J Reprod Immunol. 1990;24:105-7.

54. Szekeres-Bartho J, Par G, Dombay G, Smart YC, Volgyi Z. The anti-abortive effect of PIBF in mice is manifested by modulating NK activity. Cell Immunol. 1997;177:194-9.

55. Crncic TB, Laskarin G, Frankovic KJ, Tokmadzic SV, Strbo N, Bedenicki I, et al. Early pregnancy decidual lymphocytes beside perforin use Fas ligand (FasL) mediated cytotoxicity. J Reprod Immunol. 2007;73:108-17.

56. Crncic TB, Laskarin G, Juretic K, Strbo N, Dupor J, Srsen S, et al. Perforin and Fas/FasL cytolytic pathways at the maternal-fetal interface. Am J Reprod Immunol. 2005;54:241-8.

57. Kopcow HD, David SJ, Chen X, Rybalov B, Andzelm MM, Ge B, et al. Human decidual NK cells form immature activating synapses and are not cytotoxic. Proc Natl Acad Sci U S A. 2005;102:15563-8.

58. Koopman LA, Kopcow HD, Rybalov B, Boyson JE, Orange JS, Schatz F, et al. Human decidual natural killer cells are a unique NK cell subset with immunomodulatory potential. J Exp Med. 2003;198:1201-12.

59. Bogdan A, Berta G, Szekeres-Bartho J. PIBF positive uterine NK cells in the mouse decidua. J Reprod Immunol. 2017;119:38-43.

60. Laskarin G, Strbo N, Sotosek V, Rukavina D, Faust Z, Szekeres-Bartho J, et al. Progesterone directly and indirectly affects perforin expression in cytolytic cells. Am J Reprod Immunol. 1999;42:312-20.

61. Faust Z, Laškarin G, Rukavina D, Szekeres-Bartho J. Progesterone induced blocking factor inhibits degranulation of NK cells. Amer J Reprod Immunol. 1999;42:71-5.

62. Csapo AI. The 'see-saw' theory of parturition. Ciba Found Symp. 1997;47:159-210.

63. Par G, Geli J, Kozma N, Varga P, Szekeres-Bartho J. Progesterone regulates IL12 expression in pregnancy lymphocytes by inhibiting phospholipase A2. Am J Reprod Immunol. 2003;49:1-5.

64. Hudić I, Szekeres-Bartho J, Stray-Pedersen B, Fatušić Z, Polgar B, Ećim-Zlojutro V. Lower urinary and serum progesterone-induced blocking factor in women with preterm birth. J Reprod Immunol. 2016;117:66-9.

65. Szekeres-Bartho J, Csernus V, Hadnagy J, Pacsa AS. Influence of treatment with prostaglandin synthesis inhibitor or progesterone on cytotoxic activity and progesterone binding capacity of lymphocytes during pregnancy. Prostaglandins. 1983;26:187-95.

66. Hoffman MK, Goudar SS, Kodkany BS, Metgud M, Somannavar M, Okitawutshu J, et al; ASPIRIN Study Group. Low-dose aspirin for the prevention of preterm delivery in nulliparous women with a singleton pregnancy (ASPIRIN): a randomised, double-blind, placebo-controlled trial. Lancet. 2020;395:285-93.

67. Hudic I, Szekeres-Bartho J, Vrtacnik EB, Virant Klun I, Brkic S, Frangez HB, et al. Progesterone induced blocking factor (PIBF) taken in early pregnancy predicts the pregnancy outcome in women undergoing in vitro fertilization procedure. J Reprod Immunol. 2020;140:103150. 
68. Lim MK, Ku CW, Tan TC, Lee YH, Allen JC, Tan NS. Characterisation of serum progesterone and progesterone-induced blocking factor (PIBF) levels across trimesters in healthy pregnant women. Sci Rep. 2020;10:3840.

69. Polgár B, Nagy E, Mikó E, Varga P, Szekeres-Barthó J. Urinary progesterone-induced blocking factor concentration is related to pregnancy outcome. Biol Reprod. 2004;71:1699-705.

70. Hudić I, Stray-Pedersen B, Szekeres-Bartho J, Fatušić Z, Dizdarević-Hudić L, Tomić V, et al. Maternal serum progesterone-induced blocking factor (PIBF) in the prediction of preterm birth. J Reprod Immunol. 2015;109:36-40.

71. Liang Q, Tong L, Xian L, Shen S, Pan C, Liu C, et al. Correlations of the expression of $\gamma \delta$ T cells and their co-stimulatory molecules TIGIT, PD-1, ICOS and BTLA with PR and PIBF in the peripheral blood and decidual tissues of women with unexplained recurrent spontaneous abortion. Clin Exp Immunol. 2021;203:55-65.

72. Check JH, Levin E, Bollendorf A, Locuniak J. Miscarriage in the first trimester according to the presence or absence of the progesterone-induced blocking factor at three to five weeks from conception in progesterone supplemented women. Clin Exp Obstet Gynecol. 2005;32:13-4.

73. Check JH, Arwitz M, Gross J, Szekeres-Bartho J, Wu CH. Evidence that the expression of progesterone-induced blocking factor by maternal T-lymphocytes is positively correlated with conception. Am J Reprod Immunol. 1997;38:6-8.

74. Check JH, Arwitz M, Gross J, Peymer M, Szekeres-Bartho J. Lymphocyte immunotherapy (LI) increases serum levels of progesterone induced blocking factor (PIBF). Am J Reprod Immunol. 1997;37:17-20.

75. Salomon LJ, Rozenberg P, Szekeres-Bartho J, Malagrida L, Giudicelli Y, Ville Y. Changes in progesterone-induced-blocking-factor expression rates following mifepristone administration in termination of pregnancy at 5 to 8 weeks. J Matern Fetal Neonatal Med. 2005;17:353-6.

76. Mulac-Jeričević B, Šućurović S, Gulic T, Szekeres-Bartho J. The involvement of the progesterone receptor in PIBF and Gal-1 expression in the mouse endometrium. Am J Reprod Immunol. 2019;81:e13104.

77. Cottrell JN, Witcher A, Comley KM, Cunningham MW Jr, Ibrahim T, Denise C, et al. Progesterone induced blocking factor improves blood pressure, inflammation and pup weight in response to reduced uterine perfusion pressure (RUPP). Am J Physiol Regul Integr Comp Physiol. 2021;320:R719-27.

78. Check JH, Sansoucie L, Chern J, Amadi N, Srivastava M, Larece K. Evidence that progesterone receptor antagonists may help in the treatment of a variety of cancers by locally suppressing natural killer cell activity. Clin Exp Obste Gynecol. 2007;34:207-11.

79. Srivastava MD, Thomas A, Srivastava BI, Check JH. Expression and modulation of progesterone induced blocking factor (PIBF) and innate immune factors in human leukemia cell lines by progesterone and mifepristone. Leuk Lymphoma. 2007;48:1610-7.

80. Rozenblum E, Vahteristo P, Sandberg T, Bergthorsson JT, Syrjakoski K, Weaver D, et al. A genomic map of a 6-Mb region at 13q21-q22 implicated in cancer development: identification and characterization of candidate genes. Hum Genet. 2002;110:111-21.

81. Bischof P, Meisser A, Campana A. Paracrine and autocrine regulators of trophoblast invasion-a review. Placenta. 2000;21 Suppl A:S55-60.

82. Anderle C, Hammer A, Polgár B, Hartmann M, Wintersteiger R, Blaschitz A, et al. Human trophoblast cells express the immunomodulator progesterone-induced blocking factor. J Reprod Immunol. 2008;79:26-36.

83. Miko E, Halasz M, Jericevic-Mulac B, Wicherek L, Arck P, Arató G, et al. Progesterone-induced blocking factor (PIBF) and trophoblast invasiveness. J Reprod Immunol. 2011;90:50-7. 
84. Halasz M, Polgar B, Berta G, Czimbalek L, Szekeres-Bartho J. Progesterone-induced blocking factor differentially regulates trophoblast and tumor invasion by altering matrix metalloproteinase activity. Cell Mol Life Sci. 2013;70:4617-30.

85. Check JH, Check D. Therapy aimed to suppress the production of the immunosuppressive protein progesterone induced blocking factor (PIBF) may provide palliation and/or increased longevity for patients with a variety of different advanced cancers. Anticancer Res. 2019;39:3365-72.

86. Check JH, Sansoucie L, Chern J, Dix E. Mifepristone treatment improves length and quality of survival of mice with spontaneous lung cancer. Anticancer Res. 2010;30:119-22. 